\title{
Pengaruh Manajemen Laba Pada Agresivitas Pajak dan Implikasinya Terhadap Nilai Perusahaan
}

\author{
Made Dika Diatmika ${ }^{1}$ \\ I Made Sukartha ${ }^{2}$ \\ ${ }^{1,2}$ Fakultas Ekonomi dan Bisnis Universitas Udayana (Unud), Bali, Indonesia \\ e-mail: dikadiatmika@gmail.com
}

\begin{abstract}
ABSTRAK
Penelitian ini bertujuan untuk mengetahui pengaruh manajemen laba pada agresivitas pajak dan implikasinya terhadap nilai perusahaan. Penelitian ini dilakukan di perusahaan pertambangan yang terdaftar di Bursa Efek Indonesia tahun 2012-2017. Jumlah pengamatan yang diperoleh adalah sebanyak 51 pengamatan dengan menggunakan metode nonprobability sampling khususnya purposive sampling. Teknik analisis data yang digunakan adalah analisis jalur (path analysis). Berdasarkan hasil analisis jalur, diketahui bahwa manajemen laba dengan income decreasing tidak berpengaruh pada agresivitas pajak. Agresivitas pajak berpengaruh negatif pada nilai perusahaan. Manajemen laba dengan income decreasing berpengaruh negatif pada nilai perusahaan. Manajemen laba dengan income decreasing tidak berpengaruh secara tidak langsung pada nilai perusahaan melalui agresivitas pajak. Implikasi penelitian ini secara teoritis adalah mendukung teori keagenan dan teori sinyal sedangkan secara praktis penelitian ini dapat memberikan kontribusi positif bagi semua pihak khususnya perusahaan, pengguna utama laporan keuangan, dan juga pemerintah.
\end{abstract}

Kata kunci: nilai perusahaan, manajemen laba, agresivitas pajak

\begin{abstract}
This study aims to determine the effect of earnings management on tax aggressiveness and its implications for firm value. This research was conducted at mining companies listed on the Indonesia Stock Exchange in 2012-2017. The data analysis technique used is path analysis. Based on the results of path analysis, it is known that earnings management with decreasing income has no effect on tax aggressiveness. Tax aggressiveness has a negative effect on firm value. Earnings management with income decreasing has a negative effect on firm value. Earnings management with decreasing income does not influence indirectly on firm value through tax aggressiveness. The implication of this research theoretically is supporting agency theory and signal theory while practically this research can provide a positive contribution to all parties, especially companies, the main users of financial statements, and also the government.
\end{abstract}

Keywords: company value, earnings management, tax aggressiveness

\section{PENDAHULUAN}

Pasar modal memiliki peranan penting bagi perekonomian suatu negara karena berkaitan dengan pembiayaan perusahaan dalam jangka panjang dan sarana untuk berinvestasi bagi para investor. Menurut Tandelilin (2010), pasar modal 
merupakan sarana untuk menghubungkan pihak yang membutuhkan dana (perusahaan) dengan pihak yang memiliki kelebihan dana (investor). Tujuan investor berinvestasi adalah untuk mendapatkan keuntungan. Sementara itu, salah satu tujuan perusahaan khususnya dalam jangka panjang adalah untuk memaksimalkan nilai perusahaannya (Fama dan French, 1998).

Nilai perusahaan merupakan wujud dari rasa percaya masyarakat terhadap sebuah perusahaan (Lesmana dan Sukartha, 2017). Nilai perusahaan menggambarkan kesejahteraan para pemegang saham (Wahyudi dan Pawestri, 2006). Nilai perusahaan yang tinggi akan memberikan sinyal baik sehingga dapat menarik minat investor untuk berinvestasi di perusahaan tersebut. Nilai perusahaan yang tinggi dapat tercermin dari harga saham perusahaan tersebut. Semakin tinggi harga saham perusahaan, maka semakin tinggi pula nilai perusahaan tersebut. Oleh karena itu, salah satu cara investor untuk menilai perusahaan terkait keputusan investasi adalah melihat nilai perusahaan yang tercermin dari harga saham perusahaan tersebut. Namun, pada kenyataannya harga saham perusahaan tidak selalu sama dan selalu mengalami fluktuasi.

Fluktuasi harga saham perusahaan selalu terjadi pada perusahaanperusahaan yang terdaftar di Bursa Efek Indonesia (BEI). Salah satu fenomena fluktuasi harga saham yang menarik untuk dilihat adalah fluktuasi harga saham sektor pertambangan. Dikutip dari kontan.co.id, pada tahun 2016 saham sektor pertambangan mengalami kenaikan yang cukup tajam, sedangkan pada tahun 2017, sektor pertambangan menjadi salah satu sektor yang mengalami underperform. Fenomena tersebut mencerminkan terjadinya fluktuasi harga 
saham yang terjadi di perusahaan pertambangan. Hal tersebut dapat dilihat pada Tabel 1 berikut ini.

Tabel 1.

Fluktuasi Closing Price Lima Perusahaan Pertambangan yang Terdaftar di Bursa Efek Indonesia (BEI) tahun 2012-2017 (Disajikan dalam Rupiah per Lembar Saham)

\begin{tabular}{clllllll}
\hline \multirow{2}{*}{ No } & \multirow{2}{*}{ Perusahaan } & $\mathbf{2 0 1 2}$ & $\mathbf{2 0 1 3}$ & $\mathbf{2 0 1 4}$ & $\mathbf{2 0 1 5}$ & $\mathbf{2 0 1 6}$ & $\mathbf{2 0 1 7}$ \\
\hline 1 & ADRO & 1.590 & 1.090 & 1.040 & 515 & 1.695 & 1.860 \\
2 & ITMG & 41.550 & 28.500 & 15.375 & 5.725 & 16.875 & 20.700 \\
3 & KKGI & 2.475 & 2.050 & 1.005 & 420 & 1.500 & 324 \\
4 & PTBA & 15.100 & 10.200 & 12.500 & 4.525 & 12.500 & 2.460 \\
5 & TINS & 1.540 & 1.600 & 1.230 & 505 & 1.075 & 775 \\
\hline
\end{tabular}

Sumber: Data diolah, 2018

Berdasarkan Tabel 1 dapat diketahui bahwa harga penutupan (closing price) saham perusahaan sektor pertambangan mengalami fluktuasi sejalan dengan fenomena yang telah diungkapkan sebelumnya. Salah satu perusahaan yang mengalami fluktuasi harga penutupan yang cukup tajam adalah PT Bukit Asam (Persero) Tbk (PTBA), pada tahun 2012 hingga 2013 saham perusahaan tersebut mengalami penurunan yaitu dari Rp15.100,00 menjadi Rp10.200,00 per lembar saham. Kemudian harga saham terus mengalami kenaikan dan penurunan yang signifikan sehingga harga saham di akhir tahun 2017 menjadi Rp2.460,00 per lembar sahamnya. Harga saham perusahaan lain juga mengalami kenaikan maupun penurunan selama enam tahun terakhir. Hal tersebut mengindikasikan bahwa nilai perusahaan dapat berfluktuasi seiring dengan berfluktuasinya harga saham perusahaan tersebut.

Fluktuasi nilai perusahaan juga mengindikasikan bahwa perusahaan akan selalu berusaha untuk memaksimalkan nilai perusahaannya. Salah satu cara untuk memaksimalkan nilai perusahaan tersebut adalah dengan menciptakan keselarasan 
Made Dika Diatmika dan I Made Sukartha. Pengaruh...

dan kesinambungan tujuan maupun kepentingan antara manajer dan para pemegang saham (prinsipal). Pihak prinsipal memberikan tugas dan wewenang kepada manajemen untuk mengelola perusahaan (Kholis, 2014). Prinsipal menuntut manajemen agar mengelola perusahaan dengan baik sehingga tujuantujuan yang telah ditetapkan perusahaan dapat tercapai dan kemudian dapat meningkatkan nilai perusahaan. Namun, pada kenyataannya proses maksimalisasi nilai perusahaan seringkali terganggu oleh adanya konflik antara manajer dan pemegang saham (Tanjung, dkk., 2015). Konflik diantara kedua belah pihak tersebut sering disebut dengan konflik keagenan. Konflik akan timbul apabila manajer tidak mengungkapkan informasi yang merefleksikan seluruh informasi yang dimilikinya di dalam laporan keuangan sehingga dapat merugikan para pemegang saham.

Jensen dan Meckling (1976) menjelaskan bahwa munculnya konflik keagenan disebabkan oleh adanya asimetri informasi antara manajer dan pemegang saham. Manajer yang lebih dekat dengan kegiatan operasional perusahaan akan cenderung memiliki lebih banyak informasi yang berkaitan dengan perusahaan. Asimetri informasi tersebut membuat manajer dapat leluasa untuk melakukan manajemen laba. Manajemen laba merupakan upaya untuk mengubah, menyembunyikan, dan merekayasa angka-angka dalam laporan keuangan serta mempermainkan metode dan prosedur akuntansi yang digunakan oleh perusahaan (Sulistyanto, 2008). Perusahaan yang melakukan manajemen laba dapat menyebabkan laporan keuangan tidak lagi mencerminkan nilai perusahaan yang sesungguhnya. Hal tersebut akan berdampak pada pihak eksternal seperti 
investor sebagai pihak yang menggunakan informasi pada laporan keuangan tersebut. Investor akan mengalami kegagalan dalam menentukan investasi yang tepat dan dapat menimbulkan konsekuensi kesalahan alokasi dana kepada perusahaan yang tidak prospektif. Manajemen laba juga dapat terjadi karena adanya kebebasan penggunaan metode dan estimasi akuntansi (Bartov, 1993). Scott (2015:447) menyatakan terdapat empat bentuk manajemen laba yang dapat dilakukan oleh manajer yaitu taking a bath, income decreasing, income increasing, dan income smoothing.

Dengan adanya berbagai bentuk manajemen laba yang dapat dilakukan oleh manajer, maka perusahaan akan memilih salah satu dari berbagai bentuk manajemen laba tersebut dengan tujuan dan motivasi tertentu. Menurut Scott (2009:406) salah satu motivasi perusahaan dalam melakukan manajemen laba adalah motivasi perpajakan. Perusahaan akan berusaha untuk meminimalkan beban perusahaannya agar dapat memaksimalkan laba dan pada akhirnya dapat meningkatkan nilai perusahaan tersebut (Devi dan Supadmi, 2018). Salah satu beban yang memberatkan perusahaan dan dapat memengaruhi nilai perusahaan adalah beban pajak perusahaan.

Beban pajak perusahaan merupakan beban yang harus ditanggung oleh perusahaan dan wajib dibayarkan kepada negara. Terdapat perbedaan sudut pandang antara negara dan perusahaan dalam melihat pajak. Dari sudut pandang negara, pajak merupakan pendapatan utama untuk mempercepat pembangunan nasional di suatu negara. Hal tersebut dikarenakan sekitar 70 persen pendapatan negara bersumber dari pajak (Iqbal, 2015). Sedangkan bagi perusahaan, pajak 
dapat mengurangi laba bersih perusahaan sehingga manajemen memiliki motivasi untuk meminimalkan beban pajak yang harus dibayarkan oleh perusahaan. Tindakan manajemen untuk meminimalkan beban pajaknya ini disebut dengan agresivitas pajak (Suprimarini dan Suprasto, 2017).

Agresivitas pajak dapat dilakukan melalui tindakan perencanaan pajak baik secara legal (tax avoidance) maupun ilegal (tax evasion) yang memungkinkan manajemen untuk menghemat beban pajak perusahaannya (Frank et al., 2009). Perusahaan yang melakukan agresivitas pajak tidak hanya bersumber dari ketidaktaatannya pada undang-undang perpajakan saja, melainkan dapat pula melakukan aktivitas penghematan dengan memanfaatkan undang-undang tersebut (Ridha dan Martani, 2014).

Pada umumnya kasus agresivitas pajak yang berbentuk penghindaran pajak telah banyak terjadi di Indonesia. Dari berbagai sektor perusahaan di Indonesia, salah satu sektor yang sangat berpotensi dan kerap melakukan tindakan penghindaran pajak tersebut adalah sektor pertambangan. Dikutip dari website Asosiasi Pertambangan Indonesia dalam sebuah artikel yang ditulis oleh Dwiarto (2014), tahun 2009 telah ditemukan kasus penghindaran pajak yang dilakukan oleh Bakrie Group. Perusahaan pertambangan besar yang termasuk ke dalam Bakrie Group seperti Kaltim Prima Coal (KPC), Arutmin, dan bahkan Bumi Resources yang merupakan salah satu perusahaan yang listing di Bursa Efek Indonesia terindikasi melakukan praktik penghindaran pajak dengan jumlah 2,176 Triliun Rupiah, dengan rincian KPC sebagai penghindar pajak terbesar yaitu 1,5 Triliun Rupiah, kemudian diikuti oleh BUMI dengan total 376 Miliyar Rupiah, 
dan yang terakhir yaitu Arutmin senilai 300 Miliyar Rupiah. Fakta tersebut menyiratkan sebuah fenomena bahwa pajak adalah sebuah beban besar bagi perusahaan dalam mencapai laba yang lebih tinggi sehingga perusahaan akan cenderung melakukan penghindaran pajak untuk mengurangi beban pajaknya. Tindakan agresif perusahaan tersebut akan berpengaruh pada nilai perusahaan terutama harga sahamnya di pasar apabila publik sampai mendengar berita agresivitas pajak yang dilakukan oleh sebuah perusahaan (Dewi dan Dewi, 2017).

Penelitian terdahulu terkait dengan manajemen laba, agresivitas pajak, dan nilai perusahaan telah banyak dilakukan. Pada penelitian terkait manajemen laba dan agresivitas pajak yang dilakukan oleh Suyanto dan Supramono (2012), Kamila dan Martani (2014), Zeng (2014), Kapoutsou et al. (2015), Amidu dan Yorke (2017), dan Novitasari (2017) menunjukkan hasil penelitian bahwa manajemen laba berpengaruh positif dan signifikan pada agresivitas pajak perusahaan. Sementara itu, hasil yang berbeda ditunjukan pada penelitian yang dilakukan Putri (2014) dan Amril, dkk. (2015) yang menunjukan bahwa manajemen laba tidak berpengaruh pada agresivitas pajak perusahaan.

Kemudian pada penelitian terkait manajemen laba dan nilai perusahaan yang dilakukan Jiraporn et al. (2008), Wardani dan Hermuningsih (2012), Hwang et al. (2014), Susanto dan Christiawan (2016), dan Kamran, et al. (2018) menyatakan bahwa manajemen laba memiliki pengaruh yang positif pada nilai perusahaan. Sebaliknya, Assih, dkk. (2005), Herawaty (2008), Anggraini (2011), Gill, et al. (2013), Tangjitprom (2013), Diasari dan Suaryana (2014), Febriani dan Asmaranti (2014), dan Lesmana dan Sukartha (2017), menemukan hasil bahwa 
Made Dika Diatmika dan I Made Sukartha. Pengaruh...

manajemen laba berpengaruh negatif pada nilai perusahaan. Sedangkan penelitian yang dilakukan oleh Etemadi dan Sepasi (2007), Darwis (2012), dan Mukhtaruddin, dkk. (2014) menemukan hasil bahwa manajemen laba tidak memiliki pengaruh pada nilai perusahaan.

Penelitian terdahulu terkait agresivitas pajak dan nilai perusahaan telah dilakukan oleh Chasbiandani dan Martani (2012), Lestari (2014), Dewanata dan Achmad (2017), Dewi dan Dewi (2017) menyatakan bahwa agresivitas pajak berpengaruh positif pada nilai perusahaan. Sebaliknya, penelitian Hanlon dan Slemrod (2009), Wahab dan Holland (2012), Pradnyana dan Noviari (2017), dan Kusumayani dan Suardana (2017), menyatakan bahwa agresivitas pajak berpengaruh negatif pada nilai perusahaan. Sedangkan Desai dan Dharmapala (2005) menyatakan agresivitas pajak tidak berpengaruh pada nilai perusahaan.

Berdasarkan fenomena yang telah diungkapkan dan juga hasil penelitian terdahulu yang menunjukkan sebuah inkonsistensi, maka peneliti tertarik untuk melakukan penelitian dengan menggunakan ketiga variabel tersebut yaitu manajemen laba, agresivitas pajak, dan nilai perusahaan. Peneliti melihat terdapat sebuah dugaan bahwa jika manajemen laba yang dilakukan perusahaan dengan income decreasing akan memengaruhi agresifnya perusahaan tersebut terhadap pajak sehingga kemudian akan berpengaruh pada nilai perusahaan tersebut. Penelitian ini dilakukan pada perusahaan pertambangan yang terdaftar di Bursa Efek Indonesia (BEI) tahun 2012-2017.

Teori keagenan menggambarkan kontrak yang terjadi antara manajer dan pemegang saham. Namun, kontrak antara manajer dan pemegang saham selalu 
terganggu dengan adanya asimetri informasi dan perbedaan kepentingan diantara keduanya. Manajer sebagai pengelola perusahaan selalu memiliki lebih banyak informasi mengenai internal perusahaan dibandingkan dengan pemegang saham. Asimetri informasi tersebut adalah salah satu faktor mengapa manajer dapat melakukan manajemen laba.

Manajemen laba yang dilakukan oleh manajer dapat dimotivasi oleh beberapa faktor, salah satunya adalah motivasi pajak (Scott, 2009:406). Pajak merupakan beban yang harus ditanggung perusahaan sehingga dapat mengurangi keuntungan bersih yang dihasilkan oleh perusahaan tersebut. Maka dari itu, banyak perusahaan cenderung bertujuan untuk mengurangi beban pajak perusahaannya dengan mengurangi jumlah laba yang dilaporkan (income decreasing) untuk menurunkan laba kena pajaknya sehingga perusahaan dapat melakukan penghematan atas beban pajaknya.

Hasil penelitian yang dikemukakan oleh Frank et al. (2009) menjelaskan bahwa terdapat hubungan positif antara aggressiveness financial reporting dan tax reporting aggressiveness. Jadi, apabila perusahaan melakukan pelaporan keuangan secara agresif dalam hal ini melakukan manajemen laba dengan income decreasing, maka perusahaan juga akan semakin berperilaku agresif terhadap beban pajak perusahaan dengan melakukan penghindaran pajak. Hasil penelitian tersebut juga sejalan dengan penelitian sebelumnya yang telah dikemukakan oleh Suyanto dan Supramono (2012), Kamila dan Martani (2014), Zeng (2014), Kapoutsou et al. (2015), Amidu dan Yorke (2017), dan Novitasari (2017) yang 
menunjukkan hasil penelitian bahwa manajemen laba berpengaruh positif pada agresivitas pajak perusahaan.

$\mathrm{H}_{1}$ : Manajemen laba dengan income decreasing berpengaruh positif pada agresivitas pajak.

Teori keagenan dapat menjelaskan bahwa agresivitas pajak dapat berpengaruh pada nilai perusahaan. Ketika perusahaan menganggap bahwa beban pajak perusahaan merupakan beban yang dapat mengurangi kemampuan ekonomis perusahaan, maka perusahaan tersebut cenderung akan melakukan agresivitas pajak. Agresivitas pajak yang dilakukan oleh perusahaan juga terkait dengan upaya efisiensi biaya-biaya yang harus dibayar oleh perusahaan tersebut dalam meningkatkan laba bersih perusahaan sehingga pada akhirnya diharapkan akan berdampak pada peningkatan nilai perusahaan tersebut.

Namun, agresivitas pajak yang dilakukan oleh perusahaan memiliki risiko yang tinggi jika dibiarkan terus terjadi. Di masa mendatang, tindakan ini dapat menimbulkan biaya-biaya lebih besar serta sanksi dari fiskus yang dapat berdampak pada penurunan nilai perusahaan tersebut (Wang, 2011). Maka dari itu, perusahaan cenderung memiliki kekhawatiran lebih terhadap tindakan agresivitas pajak karena dianggap dapat mengandung hal-hal yang menguntungkan pribadi manajemen maupun dapat memengaruhi citra perusahaan apabila agresivitas pajak ini dilakukan dengan niatan negatif. Jika tindakan agresivitas pajak yang dilakukan menguntungkan pribadi manajemen atau dilakukan dengan niatan negatif, maka hal tersebut akan memberikan sinyal buruk (bad news) pada publik sehingga berdampak pada penurunan harga saham yang merupakan cerminan dari nilai perusahaan apabila hal tersebut sampai diketahui 
oleh publik. Maka dari itu, muncul sebuah dugaan bahwa semakin agresif tindakan agresivitas pajak yang dilakukan oleh manajer yang ditandai dengan rendahnya nilai GAAP ETR, maka nilai perusahaan akan semakin menurun.

Penelitian sebelumnya yang telah dikemukakan oleh Hanlon dan Slemrod (2009), Wahab dan Holland (2012), Pradnyana dan Noviari (2017), Kusumayani dan Suardana (2017), serta Devi dan Supadmi (2018) menunjukkan bahwa tindakan agresivitas pajak berpengaruh negatif pada nilai perusahaan. Hasil penelitian tersebut sejalan dengan teori keagenan bahwa asimetri informasi yang terjadi antara manajer dan pemegang saham dapat memberikan kesempatan bagi para manajer untuk berperilaku oportunistik yaitu lebih mementingkan kepentingan pribadinya daripada kepentingan pemegang saham perusahaan tersebut. Hal tersebut akan memunculkan kekhawatiran bagi para pemegang saham sehingga dapat menurunkan harga saham perusahaan dan pada akhirnya akan berdampak pada penurunan nilai perusahaan tersebut.

$\mathrm{H}_{2}$ : Agresivitas pajak berpengaruh negatif pada nilai perusahaan.

Manajemen laba yang dilakukan oleh manajer dengan menurunkan laba yang dilaporkan memiliki tujuan-tujuan tertentu. Tujuan yang memotivasi manajer dalam melakukan manajemen laba dengan menurunkan laba antara lain untuk mengurangi tingkat visibilitas perusahaan terutama pada saat periode kemakmuran yang tinggi dengan harapan memperoleh kemudahan dan fasilitas dari pemerintah, untuk mengurangi beban pajak yang harus dibayar oleh perusahaan, dan untuk memaksimalkan rencana bonus pada periode mendatang. 
Teori keagenan menjelaskan bahwa ketika manajer melakukan manajemen laba dengan income decreasing, maka kemakmuran yang akan diterima oleh pemegang saham akan mengalami penurunan (Lesmana dan Sukartha, 2017). Manajemen laba akan menyebabkan informasi yang dipublikasikan tidak mencerminkan informasi yang sebenarnya sehingga akan memberikan sinyal buruk (bad news) kepada pasar terkait hal tersebut. Pasar dalam hal ini investor akan berpikir dua kali untuk melakukan investasi pada perusahaan tersebut sehingga akan menyebabkan harga saham perusahaan cenderung akan menurun dan pada akhirnya akan berdampak pada penurunan nilai perusahaan tersebut.

Penelitian sebelumnya yang telah dilakukan oleh Gill et al. (2013), Tangjitprom (2013), Febriani dan Asmaranti (2014), dan Lesmana dan Sukartha (2017) menemukan hasil bahwa manajemen laba dengan income decreasing memiliki pengaruh yang negatif pada nilai perusahaan. Hasil penelitian tersebut sejalan dengan teori sinyal bahwa manajemen laba dengan income decreasing yang dilakukan oleh manajer dapat memberikan sinyal buruk (bad news) bagi para investor sehingga menyebabkan harga saham di pasar akan menurun dan hal tersebut mengindikasikan bahwa nilai perusahaan juga mengalami penurunan.

$\mathrm{H}_{3}$ : Manajemen laba dengan income decreasing berpengaruh negatif pada nilai perusahaan.

Manajemen laba dimotivasi oleh beberapa faktor, salah satu faktor yang memotivasi tindakan tersebut adalah motivasi pajak. Maka dari itu, manajemen laba berpengaruh pada agresivitas pajak perusahaan tersebut. Perusahaan yang agresif terhadap pajak cenderung sebelumnya melakukan manajemen laba dengan menurunkan laba yang dilaporkan (income decreasing). Dengan manajemen laba, 
harapan perusahaan adalah beban pajak dapat diminimalisir sehingga keuntungan bersih yang didapatkan akan semakin besar.

Tindakan manajemen laba dengan income decreasing secara tidak langsung dapat berpengaruh negatif pada nilai perusahaan ketika hal tersebut diketahui oleh publik dan dilakukan melalui agresivitas pajak. Hal ini dikarenakan manajemen laba dengan income decreasing yang dilakukan melalui agresivitas pajak akan memberikan sinyal buruk (bad news) yang menyebabkan publik tidak mengetahui informasi yang sebenarnya mengenai perusahaan tersebut. Manajemen laba dengan income decreasing menyebabkan publik akan melihat laba perusahaan yang telah direkayasa sehingga publik akan melakukan kesalahan dalam penilaian perusahaan tersebut. Agresivitas pajak dapat menimbulkan biayabiaya lebih besar serta sanksi dari fiskus di masa mendatang (Wang, 2011). Kedua hal tersebut akan menyebabkan berkurangnya kepercayaan investor pada perusahaan sehingga akan berdampak pada menurunnya harga saham dan pada akhirnya akan menurunkan nilai perusahaan tersebut. Hasil penelitian Suyanto dan Supramono (2012) menunjukkan bahwa semakin agresif perusahaan melakukan manajemen laba dengan income decreasing, maka dapat dikatakan bahwa tingkat agresivitas pajak perusahaan juga tinggi karena beban pajak semakin kecil dan tindakan agresivitas pajak tersebut akan mengakibatkan turunnya harga saham perusahaan. Turunnya harga saham perusahaan mencerminkan terjadinya penurunan pula pada nilai perusahaan tersebut.

$\mathrm{H}_{4}$ : Manajemen laba dengan income decreasing berpengaruh negatif pada nilai perusahaan secara tidak langsung melalui agresivitas pajak. 


\section{METODE PENELITIAN}

Penelitian ini dilakukan di perusahaan pertambangan yang terdaftar di Bursa Efek Indonesia (BEI) tahun 2012-2017. Data laporan keuangan diperoleh melalui website resmi BEI yaitu www.idx.co.id dan dari beberapa website perusahaan yang bersangkutan. Alasan peneliti memilih perusahaan pertambangan karena terdapat fenomena fluktuasi harga saham perusahaan pertambangan pada tahun 2012-2017 yang mencerminkan adanya fluktuasi nilai perusahaan. Fluktuasi nilai perusahaan tersebut disebabkan oleh beberapa faktor, salah satunya adalah dikarenakan sektor pertambangan kerap kali melakukan penghindaran pajak. Selain itu, dikutip dari website liputan6.com, sektor pertambangan pada tahun 2017 hanya berkontribusi sekitar 5,3\% terhadap penerimaan pajak di Indonesia. Hal tersebut mengindikasikan bahwa kemungkinan masih terdapat penghindaran pajak yang dilakukan oleh perusahaan-perusahaan yang termasuk dalam sektor pertambangan.

Waktu penelitian adalah periode 2012-2017 dengan alasan bahwa Ikatan Akuntan Indonesia (IAI) mensyaratkan penerapan secara penuh International Financial Reporting Standard (IFRS) pada tahun 2012. Adanya penerapan IFRS tersebut dapat memengaruhi praktik manajemen laba yang dilakukan oleh perusahaan-perusahaan di Indonesia. Selain itu, digunakannya periode penelitian sampai dengan tahun 2017 adalah untuk mendapatkan hasil yang lebih akurat dan sesuai dengan kondisi saat ini.

Rumus Tobin's Q dalam penelitian ini adalah sebagai berikut.

$$
\text { Tobin's } \mathrm{Q}=(\mathrm{MVE}+\mathrm{DEBT}) / \mathrm{TA}
$$


Keterangan:

MVE = Market Value of Equity

DEBT $=$ Total kewajiban perusahaan

TA $=$ Total aset perusahaan

Perhitungan manajemen laba dengan menggunakan modified Jones model adalah sebagai berikut.

Menghitung total akrual (Herawaty, 2008; Julio dan Yook, 2016; Susanto dan Christiawan, 2016).

$$
\mathrm{TA}_{\mathrm{it}}=\mathrm{NI}_{\mathrm{it}}-\mathrm{CFO}_{\mathrm{it}}
$$

Keterangan:

$\mathrm{TA}_{\mathrm{it}}=$ Total Akrual perusahaan $\mathrm{i}$ pada periode $\mathrm{t}$

$\mathrm{NI}_{\mathrm{it}} \quad=$ Laba Bersih perusahaan i pada periode ke $\mathrm{t}$

$\mathrm{CFO}_{\text {it }}=$ Aliran Kas dari Aktivitas Operasi perusahaan i pada periode ke $\mathrm{t}$

Penentuan koefisien regresi (Dechow, Sloan, dan Sweeney, 1995).

$\mathrm{TA}_{\mathrm{it}} / \mathrm{A}_{\mathrm{it}-1}=\beta_{1}\left(1 / \mathrm{A}_{\mathrm{it}-1}\right)+\beta_{2}\left(\Delta \mathrm{REV}_{\mathrm{it}} / \mathrm{A}_{\mathrm{it}-1}-\Delta \mathrm{REC}_{\mathrm{it}} / \mathrm{A}_{\mathrm{it}-1}\right)+\beta_{3}\left(\mathrm{PPE}_{\mathrm{it}} / \mathrm{A}_{\mathrm{it}-1}\right)+\varepsilon_{\mathrm{it}} \ldots$

Keterangan:

TAit $=$ Total Akrual Perusahaan i pada periode $\mathrm{t}$

Ait-1 = Total Aset Perusahaan i pada periode $\mathrm{t}-1$

$\triangle$ REVit $=$ Perubahan Pendapatan Perusahaan i pada periode ke $\mathrm{t}$

$\triangle$ RECit $=$ Perubahan Piutang Perusahaan i pada periode ke $\mathrm{t}$

$\mathrm{PPE}_{\mathrm{it}}=$ Aset Tetap Perusahaan i pada periode ke $\mathrm{t}$

$\varepsilon=$ error term perusahaan i pada periode ke $\mathrm{t}$

$\beta \quad=$ koefisien regresi

Menghitung Non Discretionary Accruals (NDA) dari koefisien regresi.

$\mathrm{NDA}_{i t}=\beta_{1}\left(1 / \mathrm{A}_{\mathrm{it}-1}\right)+\beta_{2}\left(\Delta \mathrm{REV}_{\mathrm{it}} / \mathrm{A}_{\mathrm{it}-1}-\Delta \mathrm{REC}_{\mathrm{it}} / \mathrm{A}_{\mathrm{it}-1}\right)+\beta_{3}\left(\mathrm{PPE}_{\mathrm{it}} / \mathrm{A}_{\mathrm{it}-1}\right) \ldots$

Keterangan:

NDAit $\quad=$ Non Discretionary Accruals Perusahaan i pada periode $\mathrm{t}$

Ait-1 = Total Aset Perusahaan i pada periode $\mathrm{t}-1$

$\triangle$ REVit $=$ Perubahan Pendapatan Perusahaan i pada periode ke $\mathrm{t}$

$\triangle$ RECit $=$ Perubahan Piutang Perusahaan i pada periode ke $\mathrm{t}$

$\mathrm{PPE}_{\mathrm{it}} \quad=$ Aset Tetap Perusahaan i pada periode ke $\mathrm{t}$

$\beta \quad=$ koefisien regresi 
Menghitung Discretionary Accruals (DA)

$$
\mathrm{DA}_{\mathrm{it}}=\left(\mathrm{TA}_{\mathrm{it}} / \mathrm{A}_{\mathrm{it}-1}\right)-\mathrm{NDA}_{\mathrm{it}}
$$

Keterangan:

$\mathrm{DA}_{\text {it }}=$ Discretionary Accruals Perusahaan i pada periode ke $\mathrm{t}$

$\mathrm{TA}_{\mathrm{it}} \quad=$ Total Akrual Perusahaan i pada periode ke $\mathrm{t}$

$\mathrm{A}_{\mathrm{it}-1}=$ Total Aset Perusahaan i pada periode $\mathrm{t}-1$

NDA $_{i t}=$ Non Discretionary Accruals Perusahaan i pada periode ke $\mathrm{t}$

GAAP ETR dihitung dengan menggunakan rumus sebagai berikut.

GAAP ETR $=$ TE $/$ PI

Keterangan:

GAAP ETR = Generally Accepted Accounting Principles Effective Tax Rate

TE $\quad=$ Tax Expense (Total beban pajak penghasilan)

PI = Pretax Income (Laba sebelum pajak penghasilan)

Populasi dalam penelitian ini adalah seluruh perusahaan pertambangan yang terdaftar di Bursa Efek Indonesia (BEI) pada tahun 2012-2017. sampel yang digunakan adalah perusahaan pertambangan yang telah listing di Bursa Efek Indonesia (BEI) pada tahun 2012-2017 yang sesuai dengan kriteria pemilihan sampel pada penelitian ini.

Teknik analisis data yang digunakan dalam penelitian ini adalah analisis jalur (path analysis), dikarenakan pengujian pengaruh variabel independen pada variabel dependennya menggunakan variabel mediasi (intervening variable). Penyusunan model juga dapat dinyatakan dalam bentuk persamaan diagram jalur yaitu sebagai berikut.

Substruktur 1

$$
\mathrm{X}_{2}=\mathrm{c} \mathrm{X}_{1}+\mathrm{e}_{1}
$$


Substruktur 2

$$
\mathrm{Y}=\mathrm{aX}_{1}+\mathrm{dX}_{2}+\mathrm{e}_{2}
$$

Keterangan:

$$
\begin{array}{ll}
\mathrm{X}_{1} & =\text { Manajemen Laba } \\
\mathrm{X}_{2} & =\text { Agresivitas Pajak } \\
\mathrm{Y} & =\text { Nilai Perusahaan } \\
\mathrm{a}, \mathrm{b}, \mathrm{c}, \mathrm{d} & =\text { Standardisasi Koefisien Regresi } \\
\mathrm{Pe}_{1}, \mathrm{Pe}_{2} & =\text { error }
\end{array}
$$

\section{HASIL DAN PEMBAHASAN}

Analisis statistik deskriptif digunakan untuk menganalisis data sehingga dapat memberikan deskripsi atau informasi mengenai karakteristik variabel-variabel yang digunakan dalam penelitian, yaitu nilai rata-rata (mean), nilai minimum, nilai maksimum, dan standar deviasi. Tujuan dilakukannya uji statistik deskriptif

\begin{tabular}{|c|c|c|c|c|}
\hline & & Nilai Perusahaan & Manajemen Laba & Agresivitas Pajak \\
\hline \multirow[t]{2}{*}{$\mathrm{N}$} & Valid & 51 & 51 & 51 \\
\hline & Missing & 0 & 0 & 0 \\
\hline & & 1,35512675 & 07789991 & ,34431248 \\
\hline & or of Mean &, 119727664 & ,007655310 & ,015615503 \\
\hline & & 1,03654110 &, 07167333 & ,31345794 \\
\hline & &, $247233^{a}$ &, $003578^{\mathrm{a}}$ &, $137190^{\mathrm{a}}$ \\
\hline & viation & ,855026543 & ,054669847 & , 111516998 \\
\hline & &, 731 &, 003 &, 012 \\
\hline & & 4,081007 & ,205076 & ,611458 \\
\hline & & ,247233 & ,003578 & ,137190 \\
\hline & & 4,328239 & ,208654 & ,748647 \\
\hline $\mathrm{Su}$ & & 69,111464 & 3,972895 & 17,559936 \\
\hline
\end{tabular}
adalah untuk mengetahui secara ringkas gambaran data mengenai ukuran pemusatan data, ukuran penyebaran data, dan kecenderungan suatu gugus data. Hasil uji statistik deskriptif dalam penelitian ini dapat dilihat pada Tabel 2.

Tabel 2.

Statistik Deskriptif Variabel Penelitian

Sumber: Data Diolah, 2018 
Berdasarkan hasil pengujian statistik deskriptif pada Tabel 2, dapat dijelaskan statistik deskriptif dari masing-masing variabel penelitian ini adalah variabel nilai perusahaan (Tobin's Q) memiliki nilai minimum sebesar 0,2472 yang berarti bahwa terdapat perusahaan pertambangan yang memiliki market value sebesar $24,72 \%$ atau dapat dikatakan memiliki nilai perusahaan yang rendah. Nilai maksimum sebesar 4,3282 berarti bahwa terdapat perusahaan pertambangan yang memiliki market value sebesar $432,82 \%$ atau dapat dikatakan perusahaan tersebut memiliki daya tarik yang tinggi bagi para investor untuk berinvestasi. Nilai rata-rata (mean) adalah sebesar 1,3551 dengan standar deviasi sebesar 0,8550 berarti bahwa perusahaan pertambangan yang menjadi sampel penelitian rata-rata memiliki nilai perusahaan sebesar 1,3551 . Nilai rata-rata ini berada di atas 1 yang berarti bahwa harga saham perusahaan di pasar lebih tinggi dari harga wajar saham tersebut (overvalued). Hal tersebut mengindikasikan bahwa pasar rata-rata tertarik untuk berinvestasi pada perusahaan pertambangan.

Variabel manajemen laba (Discretionary Accruals) memiliki nilai minimum sebesar 0,0036 yang berarti bahwa terdapat perusahaan pertambangan yang melakukan manajemen laba dengan income decreasing hanya sebesar 0,36\%. Nilai maksimum sebesar 0,2086 yang berarti bahwa terdapat perusahaan pertambangan yang melakukan manajemen laba dengan menurunkan labanya sebesar 20,86\%. Nilai rata-rata (mean) sebesar 0,0779 dengan standar deviasi sebesar 0,05467 menunjukkan bahwa perusahaan pertambangan yang menjadi sampel penelitian rata-rata melakukan manajemen laba dengan income decreasing sebesar 7,79\%. 
Variabel agresivitas pajak (GAAP ETR) menunjukkan seberapa besar upaya perusahaan menurunkan beban pajak dengan cara menurunkan laba. Variabel GAAP ETR memiliki nilai minimum sebesar 0,1371 yang berarti bahwa terdapat perusahaan pertambangan yang persentase beban pajak terutangnya sebesar $13,71 \%$ dari laba sebelum pajak. Nilai maksimum sebesar 0,7486 berarti bahwa terdapat perusahaan pertambangan yang berupaya menurunkan beban pajaknya dengan cara menurunkan laba tetapi terkena koreksi fiskal positif cukup besar yang menyebabkan persentase beban pajak menjadi lebih besar yaitu sebesar 74,86\% dari laba sebelum pajaknya. Nilai rata-rata (mean) sebesar 0,3443 dengan standar deviasi sebesar 0,1115 menunjukkan bahwa perusahaan pertambangan yang menjadi sampel penelitian rata-rata melakukan upaya penurunan pajak dengan menurunkan laba sehingga terkena koreksi fiskal cukup besar yang menyebabkan persentase beban pajak terutangnya sebesar 34,43\% dari laba sebelum pajak.

Hasil perhitungan koefisien path untuk regresi substruktur 1 dan 2 dapat dilihat pada Tabel 3 dan Tabel 4.

Tabel 3.

Hasil Analisis Jalur Regresi Substruktur 1

\begin{tabular}{|c|c|c|c|c|c|c|}
\hline \multirow[b]{2}{*}{ Model } & & \multicolumn{2}{|c|}{$\begin{array}{l}\text { Unstandardized } \\
\text { Coefficients }\end{array}$} & \multirow{2}{*}{$\begin{array}{c}\text { Standardized } \\
\text { Coefficients } \\
\text { Beta }\end{array}$} & \multirow[b]{2}{*}{$\mathbf{t}$} & \multirow[b]{2}{*}{ Sig. } \\
\hline & & B & Std. Error & & & \\
\hline 1 (Constant) & &, 343 &, 028 & & 12,404 &, 000 \\
\hline Discretionar & uals & ,018 & 291 & 009, &, 063 & ,950 \\
\hline $\mathrm{R}^{2}$ & $: 0,000$ & & & & & \\
\hline Adjusted $\mathrm{R}^{2}$ & $:-0,020$ & & & & & \\
\hline F Statistik & $: 0,004$ & & & & & \\
\hline Sig. & $: 0,950$ & & & & & \\
\hline
\end{tabular}

Berdasarkan hasil analisis jalur untuk regresi substruktur 1 yang terdapat pada Tabel 3 di atas, maka persamaan strukturalnya adalah sebagai berikut. 


$$
\begin{aligned}
& \mathrm{X}_{2}=\mathrm{cX} \mathrm{X}_{1}+\mathrm{e}_{1} \ldots \ldots \\
& \mathrm{X}_{2}=0,009 \mathrm{X}_{1}+\mathrm{e}_{1} .
\end{aligned}
$$

\section{Tabel 4.}

\begin{tabular}{|c|c|c|c|c|c|c|}
\hline \multirow[b]{2}{*}{ Model } & & \multicolumn{2}{|c|}{$\begin{array}{l}\text { Unstandardized } \\
\text { Coefficients }\end{array}$} & \multirow{2}{*}{$\begin{array}{c}\text { Standardized } \\
\text { Coefficients } \\
\text { Beta }\end{array}$} & \multirow{2}{*}{$\mathbf{t}$} & \multirow{2}{*}{ Sig. } \\
\hline & & B & $\begin{array}{l}\text { Std. } \\
\text { Error }\end{array}$ & & & \\
\hline 1 (Constan & & 2,528 &, 387 & & 6,534 & , 000 \\
\hline Discretio & Accruals & $-5,706$ & 2,005 &,- 365 & $-2,846$ & ,007 \\
\hline GAAP E & & $-2,117$ & ,983 &,- 276 & $-2,154$ & ,036 \\
\hline $\mathrm{R}^{2}$ & $: 0,211$ & & & & & \\
\hline Adjusted $\mathrm{R}^{2}$ & $: 0,178$ & & & & & \\
\hline F Statistik & $: 6,424$ & & & & & \\
\hline Sig. & $: 0,003$ & & & & & \\
\hline
\end{tabular}

Hasil Analisis Jalur Regresi Substruktur 2

Berdasarkan hasil analisis jalur untuk regresi substruktur 2 yang terdapat pada Tabel 4 di atas, maka persamaan strukturalnya adalah sebagai berikut.

$$
\begin{aligned}
& Y=a X_{1}+d X_{2}+e_{2} \ldots \ldots \ldots \ldots . . \\
& Y=-0,365 X_{1}+-0,276 X_{2}+e_{2}
\end{aligned}
$$

Sementara itu, besarnya nilai koefisien pengaruh manajemen laba pada nilai perusahaan sebelum adanya mediasi (b), yaitu sebesar $-0,367$. Berikut ini adalah hasil perhitungan dari nilai koefisien pengaruh manajemen laba pada nilai perusahaan sebelum adanya mediasi yang disajikan pada Tabel 5. 
Tabel 5.

Nilai Koefisien Pengaruh Manajemen Laba pada Nilai Perusahaan Sebelum Adanya Mediasi

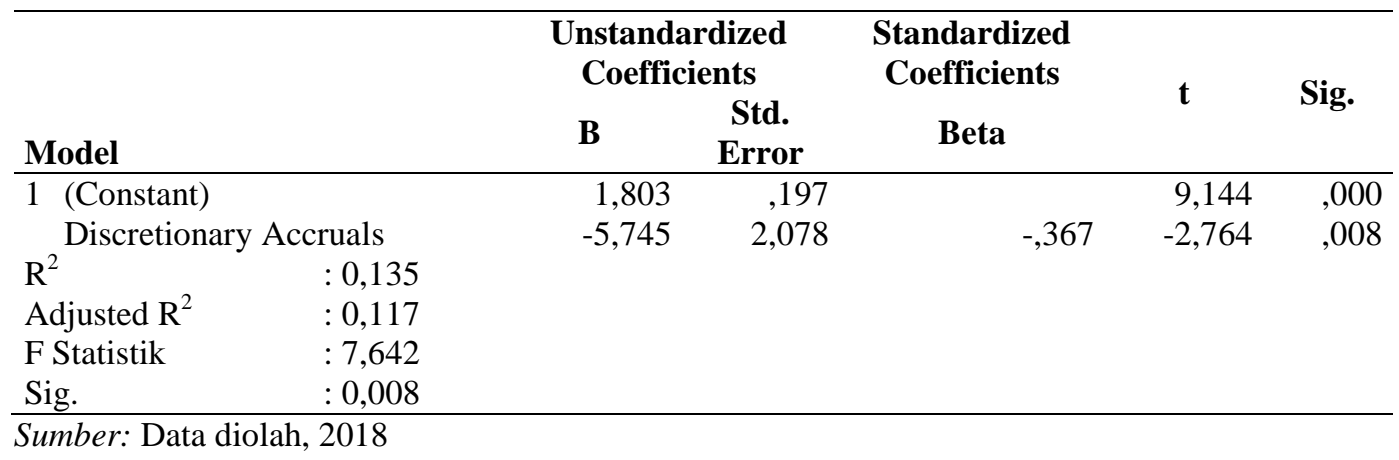

Pemeriksaan validitas model dalam analisis jalur menggunakan indikator koefisien determinasi total $\left(\mathrm{R}^{2} \mathrm{M}\right)$ dengan terlebih dahulu menghitung nilai standard error dengan perhitungan sebagai berikut.

$$
\begin{aligned}
& \mathrm{Pe}_{\mathrm{i}}=\sqrt{1-\mathrm{R}^{2}} \\
& \mathrm{Pe}_{1}=\sqrt{1-0,000}=1,000 \\
& \mathrm{Pe}_{2}=\sqrt{1-0,211}=0,888
\end{aligned}
$$

Nilai $\mathrm{R}^{2}$ untuk masing-masing regresi substruktur 1 dan 2 didapatkan dari Tabel 4.5 dan 4.6. Maka dari itu, nilai koefisien determinasi total $\left(\mathrm{R}^{2} \mathrm{M}\right)$ adalah sebagai berikut.

$$
\begin{aligned}
& \mathrm{R}^{2} \mathrm{M}=1-\left(\mathrm{Pe}_{1}\right)^{2}\left(\mathrm{Pe}_{2}\right)^{2} \ldots\left(\mathrm{Pe}_{\mathrm{p}}\right)^{2} \\
& \mathrm{R}^{2} \mathrm{M}=1-\left(\mathrm{Pe}_{1}\right)^{2}\left(\mathrm{Pe}_{2}\right)^{2} \\
& \mathrm{R}^{2} \mathrm{M}=1-\left(\left(1,000^{2}\right)\left(0,888^{2}\right)\right) \\
& \mathrm{R}^{2} \mathrm{M}=0,211
\end{aligned}
$$

Koefisien determinasi total sebesar 0,211 mempunyai arti bahwa sebesar 21,1 persen informasi yang terkandung dapat dijelaskan oleh model yang 
dibentuk, sedangkan sisanya yaitu 78,9 persen dijelaskan oleh variabel lain di luar model yang dibentuk.

Besarnya pengaruh langsung, pengaruh tidak langsung, dan pengaruh total antar variabel. Perhitungan pengaruh antar variabel dirangkum dalam Tabel 4.13 sebagai berikut.

Tabel 6.

Pengaruh Langsung, Pengaruh Tidak Langsung, dan Pengaruh Total Variabel Manajemen Laba $\left(\mathbf{X}_{1}\right)$, Agresivitas Pajak $\left(\mathbf{X}_{2}\right)$, dan Nilai Perusahaan (Y)

\begin{tabular}{llll}
\hline $\begin{array}{c}\text { Pengaruh } \\
\text { Variabel }\end{array}$ & $\begin{array}{r}\text { Pengaruh } \\
\text { Langsung }\end{array}$ & $\begin{array}{r}\text { Pengaruh Tidak } \\
\text { Langsung }(\mathbf{c ~ x ~ d )}\end{array}$ & $\begin{array}{l}\text { Pengaruh Total }(\mathbf{a}+(\mathbf{c} \\
\mathbf{x ~ d}))\end{array}$ \\
\hline $\mathrm{ML} \rightarrow \mathrm{NP}$ & $\mathrm{a}=-0,365$ & $-0,002484$ & $-0,367484$ \\
$\mathrm{ML} \rightarrow \mathrm{AP}$ & $\mathrm{c}=0,009$ & & 0,009 \\
$\mathrm{AP} \rightarrow \mathrm{NP}$ & $\mathrm{d}=-0,276$ & & $-0,276$ \\
\hline \multicolumn{2}{l}{ Sumber: Data diolah, 2018}
\end{tabular}

Hipotesis pertama menyatakan bahwa manajemen laba dengan income decreasing berpengaruh positif pada agresivitas pajak. Berdasarkan hasil analisis jalur, variabel manajemen laba dengan income decreasing memiliki koefisien regresi standar sebesar 0,009 dengan tingkat signifikansi sebesar 0,950 lebih besar dari 0,05. Hal ini berarti manajemen laba dengan income decreasing tidak berpengaruh pada agresivitas pajak sehingga $\mathrm{H}_{1}$ ditolak. Hasil penelitian ini sejalan dengan hasil penelitian yang dikemukakan oleh Putri (2014) dan Amril, dkk. (2015) yang menyatakan bahwa manajemen laba dengan income decreasing tidak berpengaruh pada agresivitas pajak.

Hipotesis kedua menyatakan bahwa agresivitas pajak berpengaruh negatif pada nilai perusahaan. Berdasarkan hasil analisis jalur, variabel agresivitas pajak memiliki koefisien regresi standar sebesar $-0,276$ dengan tingkat signifikansi sebesar 0,036 lebih kecil dari 0,05. Hal ini berarti agresivitas pajak berpengaruh 
negatif pada nilai perusahaan sehingga $\mathrm{H}_{2}$ diterima. Hasil penelitian ini sejalan dengan hasil penelitian yang dikemukakan oleh Hanlon dan Slemrod (2009), Wahab dan Holland (2012), Pradnyana dan Noviari (2017), Kusumayani dan Suardana (2017), serta Devi dan Supadmi (2018) yang menyatakan bahwa agresivitas pajak berpengaruh negatif pada nilai perusahaan.

Hipotesis ketiga menyatakan bahwa manajemen laba dengan income decreasing berpengaruh negatif pada nilai perusahaan. Berdasarkan hasil analisis jalur, variabel manajemen laba dengan income decreasing memiliki koefisien regresi standar sebesar $-0,365$ dengan tingkat signifikansi sebesar 0,007 lebih kecil dari 0,05. Hal ini berarti manajemen laba dengan income decreasing berpengaruh negatif pada nilai perusahaan sehingga $\mathrm{H}_{3}$ diterima. Hasil penelitian ini sejalan dengan hasil penelitian yang dikemukakan oleh Gill et al. (2013), Tangjitprom (2013), Febriani dan Asmaranti (2014), dan Lesmana dan Sukartha (2017) yang menyatakan bahwa manajemen laba dengan income decreasing berpengaruh negatif pada nilai perusahaan.

Hipotesis keempat menyatakan bahwa manajemen laba dengan income decreasing secara tidak langsung berpengaruh negatif pada nilai perusahaan melalui agresivitas pajak. Berdasarkan hasil analisis jalur yang mengacu pada model yang digunakan oleh Solimun (2010) didapatkan hasil perhitungan nilai koefisien $\mathrm{a}=-0,365$ dengan $\operatorname{sig} \mathrm{t}=0,007$, nilai koefisien $\mathrm{b}=-0,367$ dengan $\operatorname{sig} \mathrm{t}=$ 0,008 , nilai koefisien $\mathrm{c}=-0,009$ dengan $\operatorname{sig} \mathrm{t}=0,950$, dan nilai koefisien $\mathrm{d}=-$ 0,276 dengan sig $\mathrm{t}=0,036$. Berdasarkan hasil perhitungan tersebut, maka dapat disimpulkan bahwa agresivitas pajak dikatakan bukan sebagai variabel mediasi 
karena salah satu antara nilai c dan d yaitu nilai c adalah tidak signifikan. Hal ini berarti pengaruh manajemen laba dengan income decreasing pada nilai perusahaan tidak dipengaruhi oleh agresivitas pajak.

Hasil penelitian ini tidak sejalan dengan penelitian yang telah dilakukan oleh Suyanto dan Supramono (2012) yang menyatakan bahwa semakin agresif perusahaan melakukan manajemen laba, maka dapat dikatakan bahwa tingkat agresivitas pajak perusahaan juga tinggi karena beban pajak semakin kecil dan tindakan agresivitas pajak tersebut akan mengakibatkan turunnya harga saham perusahaan. Turunnya harga saham perusahaan mencerminkan terjadinya penurunan pula pada nilai perusahaan tersebut.

\section{SIMPULAN}

Manajemen laba dengan income decreasing tidak berpengaruh pada agresivitas pajak perusahaan. Hal ini berarti bahwa besar kecilnya manajemen laba dengan income decreasing tidak akan memengaruhi besar kecilnya agresivitas pajak yang dilakukan oleh manajemen.

Agresivitas pajak berpengaruh negatif pada nilai perusahaan. Hal ini berarti bahwa semakin tinggi agresivitas pajak yang dilakukan oleh manajemen maka dapat menurunkan nilai perusahaan apabila tindakan tersebut dilakukan dengan niatan negatif seperti mengutamakan kepentingan pribadi dan niatan negatif tersebut diketahui oleh publik.

Manajemen laba dengan income decreasing berpengaruh negatif pada nilai perusahaan. Hal ini berarti bahwa semakin tinggi manajemen laba dengan income 
decreasing maka dapat menurunkan nilai perusahaan karena manajemen laba dapat dilakukan dengan perilaku opportunistic serta akan menyebabkan informasi laba yang disajikan tidak memberikan informasi laba yang sesungguhnya (mengurangi kualitas laba yang disajikan).

Manajemen laba dengan income decreasing tidak berpengaruh secara tidak langsung pada nilai perusahaan melalui agresivitas pajak. Hal ini berarti bahwa manajemen laba dengan income decreasing tidak dapat memengaruhi agresivitas pajak yang dilakukan oleh manajemen sehingga tidak dapat memengaruhi nilai perusahaan tersebut dikarenakan terdapatnya perbedaan antara ketentuan dalam UU Perpajakan dan PSAK terkait pengakuan pendapatan dan beban karena memiliki tujuan yang berbeda.

Tindakan manajemen laba yang dilakukan baik dengan tujuan efisiensi maupun opportunistic akan mengurangi kualitas laba yang disajikan. Di dalam menilai kelayakan investasi, para investor diharapkan tidak hanya berpatokan pada informasi laba tetapi juga pada informasi fundamental perusahaan seperti analisis rasio-rasio keuangan.

Tindakan manajemen laba dan agresivitas pajak yang dilakukan dengan perilaku opportunistic dapat mengurangi nilai perusahaan. Diharapkan perusahaan dapat lebih mencegah tindakan-tindakan opportunistic serta mengevaluasi segala kebijakan yang diambil agar tidak melanggar ketentuan-ketentuan akuntansi dan perpajakan sehingga publik tetap percaya pada perusahaan tersebut serta akan menilai perusahaan tersebut baik. 
Penelitian ini memberikan hasil bahwa agresivitas pajak bukan sebagai variabel mediasi antara pengaruh manajemen laba dengan income decreasing pada nilai perusahaan. Bagi peneliti selanjutnya diharapkan dapat melakukan penelitian kembali yang dapat dilakukan di perusahaan sektor lainnya yang terdaftar di BEI untuk lebih memberikan keyakinan terkait hasil penelitian yang telah diperoleh sebelumnya di perusahaan sektor pertambangan yang terdaftar di BEI dari tahun 2012-2017.

\section{REFERENSI}

Amidu, M., dan Yorke, S. M. (2017). Tax Avoidance and Earnings Management of Firms in Ghana: Does The Funding Strategy Matter? International Journal of Critical Accounting, 9(3), 239-264.

Amril, A., Puspa, D. F., dan Fauziati, P. (2015). Pengaruh Manajemen Laba dan Corporate Governance terhadap Agresivitas Pajak Perusahaan Manufaktur yang Listing di Bursa Efek Indonesia (BEI) Periode 2011-2013. Jurnal Akuntansi Universitas Bung Hatta, 7(1).

Anggraini, L. (2011). Analisis Dampak Discretionary Accruals terhadap Good Corporate Governance (GCG). Jurnal Aplikasi Bisnis, 1(2), 84-96.

Assih, P., Hastuti, A. W., dan Parawiyati. (2005). Pengaruh Manajemen Laba pada Nilai dan Kinerja Perusahaan. Jurnal Akuntansi Dan Keuangan Indonesia, 2(2), 125-144.

Bartov, E. (1993). The Timing of Asset Sales and Earnings Manipulation. The Accounting Review, 68(4), 840-855.

Bursa Efek Indonesia. (2018). Ringkasan Harga Saham Tahun 2012-2017. http:/www.idx.co.id. Diakses 20 Mei 2018.

Chasbiandani, T., dan Martani, D. (2012). Pengaruh Tax Avoidance Jangka Panjang terhadap Nilai Perusahaan. Simposium Nasional Akuntansi XV Banjarmasin, 1-27.

Darwis, H. (2012). Pengaruh Manajemen Laba Terhadap Nilai Perusahaan dengan Mekanisme Corporate Governance sebagai Variabel Pemoderasi. Jurnal 
Keuangan Dan Perbankan, 16(1), 45-55.

Dechow, P. M., Sloan, R. G., dan Sweeney, A. P. (1995). Detecting Earnings Management. The Accounting Review, 70(2), 193-225.

Desai, M. A., dan Dharmapala, D. (2005). Corporate Tax Avoidance and Firm Value. The Review of Economics and Statistics, 91(2009), 537-546.

Devi, P. N. C., dan Supadmi, N. L. (2018). Pengaruh Agresivitas Pajak pada Nilai Perusahaan dengan Ukuran Perusahaan sebagai Pemoderasi. E-Jurnal Akuntansi Universitas Udayana, 22(3), 2257-2283.

Dewanata, P., dan Achmad, T. (2017). Pengaruh Perencanaan Pajak terhadap Nilai Perusahaan dengan Kualitas Corporate Governance sebagai Variabel Moderasi (Studi Empiris pada Perusahaan Manufaktur yang Terdaftar di BEI Tahun 2012-2014 ). Diponegoro Journal of Accounting, 6(1), 1-7.

Dewi, A. A., dan Dewi, L. G. K. (2017). Transparasi Informasi Memoderasi Pengaruh Agresivitas Pajak pada Nilai Perusahaan Pertambangan di Bursa Efek Indonesia. Akuntabilitas; Jurnal Ilmu Akuntansi, 10(2), 211-230.

Diasari, P. S. A., dan Suaryana, I. G. N. A. (2014). Real Earnings Management sebagai Prediktor Rasio Pembayaran Dividen dan Implikasinya terhadap Nilai Perusahaan. Jurnal Ilmiah Akuntansi Dan Bisnis Universitas Udayana, $9(1), 1-7$.

Dwiarto, D. (2014). Pajak Perusahaan Tambang. http://www.ima-api.com. Diakses 2 September 2018.

Etemadi, H., dan Sepasi, S. (2007). A Relationship between Income Smoothing Practices and Firms Value in Iran. Iranian Economic Review, 13(20), 25-42.

Fama, E. F., dan French, K. R. (1998). Taxes, Financing Decisions, and Firm Value. The Journal of Finance, 53(3), 819-843.

Febriani, D., dan Asmaranti, Y. (2014). Pengaruh Manajemen Laba terhadap Nilai Perusahaan dengan Mekanisme Corporate Governance sebagai Variabel Pemoderasi pada Perusahaan yang Terdaftar di Bursa Efek Indonesia. Jurnal Akuntansi Dan Keuangan, 19(1), 81-104.

Frank, M. M., Lynch, L. J., dan Rego, S. O. (2009). Tax Reporting Aggressiveness and Its Relation to Aggressive Financial Reporting. Accounting Review, 84(2), 467-496.

Gill, A., Biger, N., dan Mand, H. S. (2013). Earnings Management, Firm Performance, and the Value of Indian Manufacturing Firms. International 
Research Journal of Finance and Economics, (116), 120-132.

Hanlon, M., dan Slemrod, J. (2009). What does tax aggressiveness signal? Evidence from stock price reactions to news about tax shelter involvement. Journal of Public Economics, 93(1-2), 126-141.

Herawaty, V. (2008). Peran Praktek Corporate Governance sebagai Moderating Variable dari Pengaruh Earnings Management terhadap Nilai Perusahaan. Jurnal Akuntansi Dan Keuangan, 10(2), PP.97-108.

Hwang, N.-C. R., Chiou, J.-R., Hsueh, M.-H. E., dan Hsieh, C.-C. (2014). How Does Earnings Management Affect Innovation Strategies of Firms? Department of Accountancy California State University San Marcos.

Investing.com. (2018). Data Historis USD IDR. https://id.investing.com. Diakses 28 Agustus 2018.

Iqbal, M. (2015). Pajak Sebagai Ujung Tombak Pembangunan. http://www.pajak.go.id. Diakses 15 Mei 2018.

Jensen, M. C., dan Meckling, W. H. (1976). Theory of the Firm: Managerial Behavior, Agency Costs and Ownership Structure. Journal of Financial Economics, 3, 305-360.

Jiraporn, P., Miller, G. A., Yoon, S. S., dan Kim, Y. S. (2008). Is earnings management opportunistic or beneficial? An agency theory perspective. International Review of Financial Analysis, 17(3), 622-634.

Julio, B., dan Yook, Y. (2016). Earnings Management and Corporate Investment Decisions. Finance and Economics Discussion Series 2016-086. Washington: Board of Governors of the Federal Reserve System.

Kamila, P. A., dan Martani, D. (2014). Analisis Hubungan Agresivitas Pelaporan Pada Saat Terjadinya Penurunan Tarif Pajak. Simposium Nasional Akuntansi XVII Lombok, 1-19.

Kamran, M. R., Zhao, Z., Ali, H. S., dan Sabir, F. (2018). Does Earnings Management Mediate the Impact of Financial Policies on Market Value of Firms? A Comparative Study of China and Pakistan. International Journal of Financial Engineering, 05(01), 1850006.

Kapoutsou, E., Tzovas, C., dan Chalevas, C. (2015). Earnings management and income tax evidence from Greece. Corporate Ownership and Control, 12(2), 511-529. 
Kholis, N. (2014). Analisis Struktur Kepemilikan dan Perannya terhadap Praktik Manajemen Laba Perusahaan. ADDIN, 8(1), 203-222.

Kontan. (2018). Lesu di 2017 Saham Sektor Pertambangan dan Properti Mulai Rebound. https://investasi.kontan.co.id. Diakses 18 Mei 2018.

Kusumayani, H. A., dan Suardana, K. A. (2017). Kepemilikan Manajerial Dan Kepemilikan Institusional sebagai Pemoderasi Pengaruh Perencanaan Pajak pada Nilai Perusahaan. E-Jurnal Akuntansi Universitas Udayana, 18(1), 646-673.

Lesmana, I. P. A. S., dan Sukartha, I. M. (2017). Pengaruh Manajemen Laba pada Nilai Perusahaan Manufaktur yang Terdaftar di Bursa Efek Indonesia Tahun 2012-2015. E-Jurnal Akuntansi Universitas Udayana, 19(2), 1060-1087.

Lestari, N. (2014). Pengaruh Tax Planning terhadap Nilai Perusahaan. Akuntabilitas, 7(1), 69-83.

Martani, D. 2012. Akuntansi Pajak Penghasilan. https://staff.blog.ui.ac.id. Diakses 20 September 2018.

Mukhtaruddin, Y., Relasari, Soebyakto, B. B., Irham, A. R., dan Abukosim. (2014). Earning management, corporate social responsibility disclosures and firm 's value: Empirical study on manufacturing listed on IDX period 20102012. Net Journal of Business Management, 2(3), 48-56.

Novitasari, S. (2017). Pengaruh Manajemen Laba, Corporate Governance, dan Intensitas Modal terhadap Agresivitas Pajak Perusahaan (Studi Empiris Pada Perusahaan Property dan Real Estate yang Terdaftar di BEI Periode Tahun 2010-2014). JOM Fekon, 4(1), 1901-1914.

Pradnyana, I. B. G. P., dan Noviari, N. (2017). Pengaruh Perencanaan Pajak Terhadap Nilai Perusahaan dengan Transparansi Perusahaan sebagai Variabel Moderasi. E-Jurnal Akuntansi Universitas Udayana, 18(2), 13981425 .

Putri, L. T. Y. (2014). Pengaruh Likuiditas, Manajemen Laba dan Corporate Governance terhadap Agresivitas Pajak Perusahaan (Studi Empiris pada Perusahaan yang Terdaftar di BEI Periode 2008-2012). Jurnal Akuntansi Universitas Negeri Padang, 2(1).

Ridha, M., dan Martani, D. (2014). Analisis terhadap Agresivitas Pajak, Agresivitas Pelaporan Keuangan, Kepemilikan Keluarga, dan Tata Kelola Perusahaan di Indonesia. Simposium Nasional Akuntansi XVII Lombok. 
Scott, W. R. (2009). Financial Accounting Theory. $5^{\text {th }}$ Edition. Canada: Pearson.

Scott, W. R. (2015). Financial Accounting Theory. $7^{\text {th }}$ Edition. Canada: Pearson.

Solimun. (2010). Analisis Multivariat Pemodelan Struktural Metode Partial Least Square-PLS. Malang: Penerbit CV. Citra.

Sulistyanto, S. (2008). Manajemen Laba: Teori dan Model Empiris. Jakarta: Grasindo.

Suprimarini, N. P. D., dan Suprasto, B. H. (2017). Pengaruh Corporate Social Responsibility, Kualitas Audit, dan Kepemilikan Institusional pada Agresivitas Pajak. E-Jurnal Akuntansi Universitas Udayana, 19(2), 13491377.

Susanto, S., dan Christiawan, Y. J. (2016). Pengaruh Earnings Management terhadap Firm Value. Business Accounting Review, 4(1), 205-216.

Suyanto, D. K., dan Supramono. (2012). Likuiditas, Leverage, Komisaris Independen, dan Manajemen Laba terhadap Agresivitas Pajak Perusahaan. Jurnal Keuangan Dan Perbankan, 16(2), 167-177.

Tandelilin, E. 2010. Portofolio dan Investasi: Teori dan Aplikasi. Edisi Pertama. Yogyakarta: Kanisius.

Tangjitprom, N. (2013). The Role of Corporate Governance in Reducing the Negative Effect of Earnings Management. International Journal of Economics and Finance, 5(3), 213-220.

Tanjung, M., Sucherly, Sutisna, dan Sudarsono, R. (2015). The Role of Good Corporate Governance in Minimizing Earning Management to Increase Value of Firm. International Journal of Scientific dan Technology Research, 4(09), 21-27.

Wahab, N. S. A., dan Holland, K. (2012). Tax Planning, Corporate Governance, and Equity Value. The British Accounting Review, 1-43.

Wahyudi, U., dan Pawestri, H. P. (2006). Implikasi Struktur Kepemilikan Terhadap Nilai Perusahaan: Dengan Keputusan Keuangan sebagai Variabel Intervening. Simposium Nasional Akuntansi 9 Padang, 53, 160.

Wang, X. (2011). Tax Avoidance, Corporate Transparency, and Firm Value. SSRN Electronic Journal.

Wardani, D. K., dan Hermuningsih, S. (2012). Earnings Management and Firm 
Value with Investment Opportunity Set (IOS) as Moderating Variable: Comparative Study in Indonesia and Malaysia. The 13th Malaysia-Indonesia International Conference on Economic, Management, and Accountig (MIICEMA), 1-15.

Zeng, T. (2014). Earnings Management around Tax Rate Reduction: Evidence from China's 2007 Corporate Tax Reform. Asian Review of Accounting, $22(3), 304-317$. 